\title{
The Dynamics of the East African Market
}

\author{
Jokull Johannesson (Corresponding author) \\ University of Northampton Park Campus \\ Boughton Green Road, Northampton, NN2 7AL, UK \\ Tel: 44-1604-732-088Ｅ-mail: jokull.johannesson@northampton.ac.uk \\ Iryna Palona \\ University of Liverpool Biosciences Building \\ Crown Street Liverpool L69 7ZB, UK
}

\begin{abstract}
The establishment of the East African Community (EAC) Internal Market in 2010 creates a market of 126 million people. This article reviews the dynamics of marketing in the EAC by describing the history of the EAC formation, the socio-economic situation, and the role of factor investment in laying the foundation for rapid economic growth. Moreover the development of the retail environment in the EAC and the corresponding successful marketing mix strategies are described. The typical business strategy, structure, and rivalry and the role of chance are discussed as well as managerial implication for organizations entering or operating in the particular characteristics of the EAC market.
\end{abstract}

Keywords: East African Community, Marketing, Emerging markets

\section{Introduction}

Globalization takes companies on eternal search for market niches for their goods and services worldwide and much focus has been on emerging markets in China and South-East Asia. However the emerging markets in the five countries of the East African Community (EAC)- Kenya, Uganda, Tanzania, Burundi, and Rwanda have received little attention in the academic literature or the popular media. There are few if any articles published on marketing in the EAC and a search on Google Scholar shows no recent published studies on marketing in the EAC and only one or two on general business related topic. Moreover the news coverage of the EAC is negative and pictures show images of war and famine. This image of the EAC is deceiving and hides the fact that the region is experiencing rapid economic growth as indicated by the region's economic growth in 2008 which was $6.8 \%$ and the projections for 2009 and 2010 are even better at 7.5\% (EAC Int, 2010). Albeit the lack of published research on marketing and doing business in the EAC, the corporate sector is taking notice of the fantastic growth opportunities in East Africa as many sectors are recording phenomenal growth and profits. Retailers like Metro and ShopRite are investing heavily in the region and many international banks with operations in East Africa are experiencing record growth and return on investment. Capital investment is flourishing and the number of stock exchanges has risen from one in 1989 to 3 in 2009.

The rapid economic growth and the rise of the middle classes in the EAC particularly in Kenya and Uganda have transformed the business environment in these countries and over the past decade dramatic structural changes in the retail sectors have taken place in the EAC. Previously the retailing industry was primarily based on outdoor markets and over the counter stores but now the retail market has been transformed to a large extent to self-select supermarkets, convenience stores, and large supermarkets. The fastest transformation is happening in Kenya and Uganda. Consequently the East African Community (EAC) presents an attractive market that should not be dismissed and presents attractive investment opportunities in a number of sectors such as trade, tourism, telecommunications, agriculture, fishing, mining, textiles, chemicals, electronic equipment, and motor vehicles (UNCTAD, 2000; UNCTAC/ICC, 2001; Darley, 2001; EAC Int, 2010).

Whereas there is a lack of published papers on marketing in the EAC we contribute to the knowledge of the issues and challenges in marketing in the East African Community. First we will introduce the East African Community then we will discuss and describe the socio-economic environment, factor investment, retail environment, marketing mix strategies, the strategies, structure, and rivalry of firms, the role of chance, and managerial implication of marketing in the East African Community.

\section{History of the East African Community}

The co-operation among Kenya, Uganda, and Tanzania dates back to the time the two first countries were 
colonies of the United Kingdom (UK). Tanzania was German colony but after the WWI Tanzania came under UK and remained under UK administrated United Nations trusteeship until independence in 1964. Since various co-operative agreements have been in force including a Ugandan/Kenya Customs Union established in 1917 which Tanzania joined in 1927. The East African High Commission functioned from 1948 to 1961, the East African Common Services Organization was established in 1961 and remained until it was succeeded by the establishment of the East African Community in 1967.

In 1977, interregional co-operation came to an end but it resumed with the signing of the East African Co-operation agreement in 1993. Since various co-operative treaties and agreements have been initiated and lead to the formation of the East African Community on July 7th, 2000 by a treaty among Kenya, Tanzania, and Uganda. The establishment of the EAC set into motion further collaborative protocols between the nations and included agreements on standards, crime prevention, establishment of free trade area, integrated economic development strategy, scientific and technological collaboration, establishment of legislative assembly, courts, and East African Customs Union, which was formally activated in November 2004 with the objective of creating a customs free internal market and harmonized external tariff rates In 2007, Rwanda and Burundi joined the EAC which increased the population to 126 million people and agreement was reached to eliminate all internal tariffs and allow free movement of people by July 2010 (CIA, 2004 \& 2010, EAC 2004a \& b; BBC, 2009; EAC Int, 2010).

\section{Socio-Economic Situation}

At formation the EAC had a large and fast growing population of 92.8 million people and at a growth rate in excess of $3 \%$ the population of the founding three EAC counties- Kenya, Uganda, and Tanzania was projected to be 122 million by 2015. When Burundi and Rwanda joined the EAC in 2007 the population jumped to 126 million (UNDP, 2004; EAC Int, 2010). In 2004 the Purchasing Power Parity GDP was USD100 billion and by 2008 it had jumped to USD163 billion (UNDP, 2004; Nord, et. al., 2004; CIA, 2010). However the actual GDP may be much higher because unreported income and fraud are widespread and because much of the economic activity in small agricultural economies goes unrecorded in economic statistics (Kigotho and Bollag, 2002).

A further indication of this underestimation of the actual GDP in EAC countries can be observed by looking at the differential in the growth rate of the broad money supply and inflation. The broad money supply grew at average rate of $13.68 \%$ from $1997-2004$ but the inflation was at an average rate of only $5.6 \%$. Whereas increased broad money supply over a sustained period of time should lead to inflation if the size of the economy remains constant then the fact that inflation did not rise at par with the growth in the broad money supply indicates a growth in economic activity that has gone unrecorded. Consequently, the actual GDP of the EAC countries may be twice or as much as three times greater than has been recorded. A supporting statistic was the high domestic savings and investment rates of 11.2-13.9\% and 16.5-19.6\% of GDP respectively for the period 1997 to 2004 and increasing to more than $20 \%$ in 2008 which would normally lead to inflation if they were properly reflected in the economic statistics (Nord, et. al., 2004; CIA, 2010).

Uganda has moved away from Maoist economy of absurd poverty, dependence on foreign exchange controls, and inefficient state run enterprises to market driven free economy. Most of the former state own enterprises have been sold and are now operated at a profit instead of being dependant on government subsidies and protection. The Ugandan currency exchange rate floats although the Bank of Uganda maintains the exchange rate in certain range with direct market intervention. In 2004, the GDP per capita was USD402 and it was growing at $5.5 \%$, and inflation remained at $3.5 \%$. However by the end of the decade the growth rate had risen to $8.3 \%$ and the inflation rate to $12.4 \%$ while the interest rate rose to $20 \%$ which showed inflationary pressures in the economy. In 2002, official foreign aid was USD606 million and remained in that range for the rest of the decade, the capital formation stood at $22 \%$ of GDP and had risen slightly by 2008 . The agriculture sector contributed $31 \%$ of the GDP, industry $21 \%$, and services $46 \%$. The reduction of public debt from $73 \%$ of GDP in 2004 to $18 \%$ in 2008 was a positive development ((Juuko, 2004; UNCTAD, 2004; World Bank, 2004 \& 2009; CIA, 2010).

Kenya has made similar transition to a free economy and Kenya has achieved surprising success in cement, capital markets, banking, road transportation, and some transport and machine manufacturing industries. Kenya is a regional manufacturing, commercial, transportation, and financial hub for East Africa. The coffee, tea, and flower industries have achieved international quality standards. The Mombasa tea auction is the world's second largest in volume and the largest in terms of export. The Kenyan based Africa Online is one of Africa's premier internet service providers. The Nairobi Stock Exchange was established in 1954, and is the fourth largest in Sub-Saharan Africa (NSE, 2005). In 2003, the GDP per capita was USD437 and was growing at $1.2 \%$, the 
inflation was $6.6 \%$, and economic growth improved later in the decade with a peak of $7.3 \%$ in 2007 . However political turmoil and world recession limited the GDP growth to $2.2 \%$ in 2008 . Kenya has been plagued by corruption and graft and in ranked by Transparency International as the second most corrupt country in the world after Nigeria. Consequently the International Monetary Fund suspended lending in 1997 but it lent Kenya USD252 million in 2000-2001. The IMF has suspended lending intermittingly since. Kenya's gross investment stood at $21 \%$ of GDP in 2008 . The agriculture sector contributed $15 \%$ to the GDP, industry $19 \%$, and services 64\% (Omondi, 2001; Redfern, 2004; Transparency International, 2006; World Bank, 2004 \& 2009; CIA, 2010).

Tanzania began its economic reforms in 1992 with the privatization of many state owned enterprises, removal of exchange controls, and free competition in many economic sectors. However Tanzania is lagging behind in economic development because of stubborn attachment to obsolete Maoist economic policies which limited the country's economic progress in a host of economic sectors. Tanzania is well endowed in natural resources such as large fertile land, gold, gemstones, iron ore, natural gas, and opportunities to develop its tourism and fishing industries. Manufacturing is limited but has great potential (USCS, 2005). In 2004, the GDP per capita was USD235 and it was growing at $4.3 \%$, the inflation was $4.3 \%$ and was decreasing. In 2002, investment was $17 \%$ of GDP and had grown to $23 \%$ by 2008 . The agricultural sector contributed $45 \%$ of the GDP in 2001 but had declined to $27 \%$ in 2008 , when industry had grown to $22 \%$ and services had risen to $50 \%$ of GDP (UNCTAD, 2004; CIA, 2010).

Rwanda's economy is based on subsistence agriculture with coffee and tea as main exports. Industrialization is minimal. The country is critically dependent on foreign aid and remittances of salaries by Rwandan's living abroad. The 1994 genocide devastated the economy which has not recovered since. Albeit 10-12\% growth in the GDP in the past decade the economy was in a poor state and the Rwandan government's involvement in the conflict in the Democratic Republic of Congo drained the country's scarce resources and resulted in millions of refugees from neighboring countries (EAC Int, 2010; CIA, 2010).

Burundi's economy is the smallest in the EAC with a GDP of USD1 billion in 2008 which had grown at $4 \%$ for the years 2006-8. The ongoing ethnic war between the Tutsi and majority Hutu tribe stifled economic growth and Burundi is critically dependent on foreign aid (EAC Int, 2010; CIA, 2010).

\section{Factor Investment}

The factor investment in Africa is unique as much of the capital comes from official foreign aid. In 2004 the world richer nations mostly the United Sates and EU countries donated USD50 billion to Africa and British Prime Minister Mr. Brown called on the richer nations to double their contributions (Sylvester, 2005). In addition to the public foreign contributions are the donations made by foundations, relief agencies, and individuals, these result in an unprecedented inflow of capital which goes for the development of factor conditions such as infrastructure, education, and healthcare. In 2004 the foreign direct investment (FDI) was USD20 billion which compares favorably to China's FDI of USD60.6 billion (UNCTAD, 2005; People's Daily, 2005). As a result of high foreign factor investment and FDI the gross investment in Uganda, Kenya, Tanzania, and Rwanda exceeds $20 \%$ of GDP for most of the decade. Albeit the gross investment in Burundi was somewhat less it was never the less impressive at $12 \%$ in 2008 . The factor investment in education and training has been significant in the nations of the EAC and the UN estimated that adult literacy rate as $70-80 \%$ in 2005 , and primary school enrollment to be $100 \%$ in Uganda, $97 \%$ in Kenya and $47 \%$ in Tanzania. In addition to the factor investment overseas workers called "Keiyo" infuse significant amount of capital into the region and the repatriated salaries may exceed the value of the region's largest export commodity coffee (World Bank, 2004; UNCTAD, 2004; EAC Int, 2010; CIA, 2010).

\section{Retail Environment in the EAC}

The EAC is a relatively small market characterized by unsophisticated demand conditions as most customers needs are basic but the rising level of affluence in the EAC has increased the consumer's sophistication and demands for greater selection of medium quality products. The retail sector in the EAC has undergone a radical transformation in the last decade as it formalized with significant portion of the market converting from small shops, outdoor markets and kiosks to supermarkets and large retail stores (Wijk, 2006). Albeit this general trend each of the EAC countries is different and the following section analyses the retail environments in Kenya, Uganda, Tanzania, Rwanda, and Burundi.

Kenya has the most advanced retail market in the EAC. Small shops number in the tens of thousands and there are more than 300 supermarkets in the country. For example, the capital- Nairobi has 138 independent supermarkets, 45 supermarkets operated by supermarket chains, 12 hypermarkets, 5 shopping malls, and hundreds of specialty retail stores. The Kenyan supermarkets have approximately $30 \%$ of the retail markets share 
in the country (Weaherspoon and Reardon, 2003; FAO, 2005; Virtual Nairobi, 2005; Wijk, 2006). The Kenyan based Nakumatt supermarkets is the EAC's largest supermarket chain with plan to operate 40 supermarkets by December 2010, thirty will be in Kenya, four in Tanzania and Uganda and Rwanda will have three each (Ramamurthy, 2009). Uchumi is EAC's second largest supermarket chain with 27 supermarkets in Kenya and one in Uganda. In 2004 an unknown strategic investor acquired 35\% equity stake in Uchumi and the company planed to use the funds to strengthen its balance sheet and finance growth (Muna, 2004). However the Uchumi's rapid expansion strategy got the supermarket chain into trouble in 2006 when it filed for insolvency protection. However improvements in operation resulted in a 60\% rise in profitability in 2009 and the management planes to emerge from insolvency protection on February 1, 2010 (Reuters, 2010). Smaller Kenyan supermarket chains include Tusker, Mattresses, and Ukwala. Foreign retailers have entered the market and they include ShopRite, Metro Cash\&Carry, and Woolworths. Woolworths stores had 5 stores by 2010 but the future of Woolworths operations remains uncertain after the bankruptcy of the UK parent company in 2009 (Weatherspoon and Reardon, 2003; BBC, 2009; Woolworths, 2010). Furthermore fast food outlets, furniture stores, petrol stations, and convenient stores have experienced rapid growth in Kenya.

The Ugandan retail market has gone through a dramatic transformation. In the early 1990s, most retailing was done in small shops, outdoor markets, and kiosks. Only a handful of medium size stores existed in the country. Today much of the retail operation has moved to independent supermarkets, chains of convenience stores, and supermarket chains. Furthermore foreign retailers have noticed the potential of the market in Uganda and the first large hypermarket was established by Metro Cash\&Carry in 1998. Initially Metro Cash\&Carry operated as wholesale discount store with a retail concept similar to the Wal-Mart's Sam's Club concept but later the management changed the format and opened the doors to the public. Also Metro Cash\&Carry established a number of the smaller KwickSave supermarkets around the country. In 2000 ShopRite followed and opened two stores. Woolworths followed in 2002 and established two upscale department stores still operating in 2010 but the future of these stores is uncertain after the bankruptcy of the UK business in 2008. Megasave and the Kenyan Uchumi supermarket chain entered the market in 2004 with one supermarket each (PWC, 2005). In the mid 1990s the government liberalized the petroleum import and distribution industry which resulted in quadrupling of the number of petrol stations. In 1996 Shell Uganda opened the first convenience store in the country at the Bugalobi Shell petrol station. Since then convenience stores have been set up at most petrol stations. Additionally foreign fast food chains and furniture stores have entered the market in Uganda.

The Tanzanian retail environment is undeveloped as its development has been hindered by outdated communist policies. Consequently the development of the Tanzanian retail market did not start until the late 1990s when some of these communistic policies were lifted. The development pattern of the retail sector was similar to that of the retail sector in Uganda. First there was a proliferation of small over the counter shops, second was an introduction of small self-select supermarkets, third was the establishment of larger domestic supermarkets chains like the Imalaseko and Shoppers' Plaza, and finally the entry of the South African retail chains- ShopRite and PnP in 2000. However in 2003, PnP pulled out of Tanzania by selling its 4 stores to ShopRite. Woolworths had one store by 2010. In 2004, Megasave and Usave established presence in Tanzania with one store each (Weatherspoon and Reardon, 2003; Woolworths, 2010). However the development of the supermarkets in Tanzania was rapid and by 2006 there were 48 supermarkets operating in the country (Wijk, 2006).

The retail environments in Rwanda and Burundi consist primarily of outdoor markets and small over the counter shops. Six medium size super markets operated in Kigali in 2009 and four in the capital of Burundi. In 2008 the Nakumatt supermarket chain entered the Rwandan market via a buyout of the City Supermarket store in Kigali and Nakumatt plans to have three supermarkets in 2010 (Barigye, 2008; Ramamurthy, 2009).

\section{Marketing Mix Strategy for the EAC}

The following section reviews the product- and distribution strategies, price elasticity of demand, and promotion in the EAC.

\subsection{Product strategy}

Prior to the recent transformation of the retail industries in the EAC, most products were sold in open markets and small over the counter stores. Typically the merchants bought items in bulk and package the goods in plastic bags. The recent transformation of the retailing industry to a more formal retail environment such as self-select small stores and supermarkets has lead to the need for low cost standardized products of fair or average quality but relatively few features, and options. Trademarks and brands have become important and it is particularly important to emphasize the national origin of the product as they are perceived of higher quality and prestige. In the EAC "Made in UK" and "Design in Japan" are particularly popular. Consequently the global packaging does 
not need to be changed if the brand names are in English. However the packaging should be tailored to the needs of price conscious customers. Therefore expensive packaging in blister packs and in multiple sizes is a waste of money. In most cases, one or two sizes of consumer packaging and one wholesale size packaging will do. For an example, most of the cooking oil is retailed in $500 \mathrm{ml}$ or 1 liter bottles or, 20 liter jerry cans for restaurants and retailers who will sell the cooking oil in containers brought in by the customers or in ordinary plastic bags. Warranties are not provided for most products and most sales receipts carry a "No Returns" note at the bottom.

\subsection{Distribution strategy}

Although the distribution channels selected depend on the goods sold, intensive distribution channels are most appropriate for most consumer goods as most customers don't have personal transportation therefore they do most of their shopping in local stores and supermarkets. The distribution channels are typically long and rely on multiple levels of agents and distributors. Often manufacturers sell their production at the factory door to authorized distributors who transported the goods at their own cost to wholesale markets such as the Nakivubo wholesale market in Kampala. These wholesale markets sell to retailers who arrange transportation of the goods to their retail outlets. However in the last 10 years, the trend has been to shorten the distribution channels by direct deliveries from manufacturers to retail stores. Larger supermarkets purchase directly from producers and importers.

A push channel strategy is most appropriate for basic consumer goods because most customers have limited exposure to mass promotional devises such as newspapers, radio, and TV. The emphasis on push channel strategy in East Africa concurs with the findings of researchers investigating distribution strategies in other emerging economies (Batra, 1997; Samiee, 1993; Mueller, Wenthe, and Baron, 1993). However a combination of push and pull policies would be appropriate for goods targeting the growing middle class customers as they will have greater access to the mass media.

In the EAC there are a few distribution centers and the ones there are owned by domestic supermarket chains. In 2007 ShopRite purchased PnP's distribution center in Tanzania and Metro Cash\&Carry has a distribution center in Nairobi. In Uganda, there are no distribution centers as such and Metro Cash\&Carry uses its main store at the Showgrounds as a distribution center for its KwickSave network of stores. Warehouses and storage yard space are sufficient in Kenya and Tanzania but, warehouse space is limited in Uganda particularly around the capital, Kampala, where hills make the construction of warehouses difficult. The situation is similar in Rwanda's capital Kigali which is also built on series of hills. As of 2009 distribution in Uganda, Rwanda, and Burundi is characterized by wholesale market streets like the Nakivuvo market street in Kampala where hundreds of small cash and carry shops function as distributors for manufacturers and importers. Refrigerated warehouse space is very limited in all the EAC countries, material handling equipment is in short supply and most loading is done manually. In terms of location, retail outlets need to be located close to major public transit areas such as bus and taxi parks in order to attract customers and facilitate the customer's transportation of goods to their homes as most customers do not have private transportation.

Inventory requirements are higher in the EAC than in more developed countries because of the long transport distances, poor infrastructure, and bureaucratic delays which all contribute to longer delivery times and frequent interruptions in supply.

Most road trucks are general purpose flatbed or stake-bed trucks, container carriers, and tankers. Gross vehicle weight is harmonized at 56 tons for a seven axle truck-trailer combination with maximum axle loading of 8 tons on steering axle and 10 tons on other axles. Specialized trucks are limited in number. The demand for trucks is seasonal and related to the harvest seasons which are February to end of May and September to end of December when trucks are in short supply. This is particularly troublesome during the second harvest season which coincides with the surge in demand for transportation of imports for the Christmas shopping season. The rates for road transport are approximately ten US cents per ton per kilometer but, lower charges apply to exports because of a lack of back-freight to the ports of Mombasa and Dar es Salaam.

The railway system in EAC is debilitated due to mismanagement and only a fraction of the network actually works and when it does work the system is plagued with delays and corruption. For example, Uganda has 1241 $\mathrm{km}$ of railways but only $220 \mathrm{~km}$ of the rail system is functional (CIA, 2010). There are two main railway lines in the EAC. The northern corridor lies from Mombasa, Kenya, to Kampala, Uganda, with a branch line to Kisumu in Kenya. The southern corridor starts in Dar es Salaam, Tanzania and goes to Mwanza on the shores of Lake Victoria where there is a ferry to Kampala. The cost of rail transport is slightly lower than compatible road transport. Road and rail transport is risky and plagued by delays due to poor infrastructure, bureaucracy, insurgency, and criminal activity. Trucks and trains rarely move after dark. 
The air transport is mainly used for the export of fresh fish, fruit, vegetables, and flowers. The exporters complain of periodic shortage of air cargo space and high transport charges. The exports exceed imports on most destinations except Dubai and Johannesburg. Hence import air cargo rates are one half of the export rate which was USD0.75 per $\mathrm{kg}$ from Kampala to London in 2009. The value of the exports carried by airfreight is significant. For example the exports from Kenya were valued at USD300 million in 2009 (EAC Int, 2010).

On July 1, 2005, external tariffs for the EAC countries were harmonized and set at three levels according to how much the imports have been processed. Raw materials have zero tariff, semi-processed goods have $10 \%$ rate, and manufactured goods $25 \%$ tariff (Odeu, 2004). Internal tariffs among the three countries were eliminated with the exception of certain Kenyan goods which were charged 2-25\% import duty in Uganda and Tanzania according to a list of 762 items published by the EAC on January 16, 2005. All import duties among the three countries will be phased out by the 2010 (Kasumuni, 2005; BBC, 2009: EAC Int, 2010). In the past there have been various restrictions on specific imports into the EAC countries, the obvious one being on the importation of arms and ammunitions of any type. Other restrictions vary by country and the restrictions are often meant to protect an industry or a specific company. For an example Uganda prohibited the importation of lead acid batteries for vehicles to protect the Uganda Battery Ltd the country's only battery manufacturer.

In the EAC most tools, parts, and production machinery are imported and the local sourcing of spare parts is hampered by underdeveloped spare part distribution system. Most companies of any size get their spare parts delivered directly from abroad via express courier or import their own stock of spare parts. Furthermore, there is a critical shortage of trained technicians and maintenance personnel so most firms initiate in-house training and apprenticeship programs. For these reasons maintenance costs are increased and productivity of existing facilities and equipment is decreased due to extended downtimes caused by lack of spare parts and poor quality repairs and maintenance.

\subsection{Price elasticity of demand}

The customers in EAC tend to be highly sensitive to price. Hence the elasticity of demand is high. Pricing strategies are the prime questions merchants face when deciding on positioning their businesses in the EAC. The international retailers Nakumatt, Metro, ShopRite, and PnP, are the price leaders and they targeted the mass market and the low/and middle class consumers from the start (Weatherspoon, 2003). Special discount pricing or promotional pricing is rarely used but merchants who have experimented with discounting have achieved significant success. The prices on most consumer goods are fixed. However price negotiation is the norm on large ticket items such as electronics and home appliances and it is considered rude it the merchant is not willing to negotiate the price approximately $10 \%$ percent. The price of most goods and services rises during the Christmas shopping season from late November to the end of the Christmas holiday season which is in the second week of January. The prices of all produce and food stables are seasonal and the transport prices are seasonal as mentioned above. Merchants need to give special concerns to export pricing as the value added tax, exercise and import duties are refundable on goods that are re-exported. The firms in the EAC have re-export opportunities to Democratic Republic of Congo, Sudan, Zambia, Malawi, Zimbabwe, and Mozambique (Trent, 2002; CIA, 2010).

\subsection{Promotion}

The product and the target market determine the media, timing, reach, frequency, and continuity of advertising in EAC. The media of choice is radio as it is the most accessible medium for the general public for several reasons. First, radio listening is a low cost, most accessible, and popular mass medium for the general public where illiteracy is common. Second, tradio advertising is the cheapest alternative for marketers in comparison to the reach of other mediums. Third, most people have radios on all day at home and work. Fourth, public transport such as buses and minibuses pipe the radio to loud speakers in the back of the vehicles for the entertainment of passengers. The best timing of radio advertising depends on the product but for mass consumer products the morning and evening rush hours are the best times because of the captive audience in the public transport system. The morning rush hours are between 7-10AM in Uganda, Rwanda, Burundi, and Tanzania and 6-9AM in Kenya. The evening rush hours are 5-10PM and 5-9PM respectively. High advertising frequency is important and continuity is typically much longer than in developed countries. The messages need to be localized to the languages most commonly used. In Kenya and Tanzania, Kiswahili is the lingua franca but, in Uganda most messages are in Luganda in the capital or the regional tribal languages in the countryside. In Rwanda and Burundi the messages are in local languages: Kinyarwanda, Kirundi; or French, English, and Kiswahili. Advertising messages contained in musical lyrics and sing-a-longs appear to be particularly effective.

Alternatively billboards are common and appear to be effective in promoting brand names. However news paper 
and TV advertising are expensive by comparisons to their reach. The burgeoning use of mobile phone SMS messages and the opportunity to use SMS messages as an advertising medium is an unexplored opportunity in the EAC (Ochieng, 2009).

Sales promotions like contests and sweepstakes have been successful for soft drink bottlers and breweries but few other marketers have adapted this method. The use of samplings and demonstrations to promote products are rare. Yet, they have promising prospects as a low cost personalized medium. Warranties or guarantees are rarely issued. Personal selling has great potential in the EAC because of the low cost of the local labor and sales personnel should be recruited and trained locally and motivated by commissions to encourage performance. Although salary and commissions are usually paid monthly, employees have difficulty with budgeting for that long a period therefore weekly or biweekly payments increase moral and reduce fraud. Moreover effective controls of stock and money are paramount because of high levels of corruption and fraud (Transparency International, 2006).

\section{Firm strategy, structure and, rivalry}

In the EAC the competitive strategies of firms are mostly based on price because of the high price elasticity of demand and unsophisticated marketing culture. The organizational structures of most businesses are highly hieratical with multiple layers of manager who exercise little decision power as most decisions are centralized in the owner or the managing director. A wave of privatization has significantly reduced the government ownership of businesses. However government officials own many businesses and the ownership is either overt or covert through agents or family members. The Asian community who are people originating from the Indian Sub-Continent, control significant portion of economic activity in the EAC (Kristiansen \& Ryan, 2002). Nairobi has the largest stock exchange with active public ownership of companies and many of the companies listed are local subsidiaries of multinational companies. However most companies in the EAC are family owned. In general competitive rivalry is low and responses to competitive behavior are slow and usually they do not materialize until sales and profits have dropped to unaccepted levels. Price collusions and cartels are common and reduce rivalry.

\section{Role of Chance}

Chance events are independent of a nation and firms have limited ability to influence them (Porter, 1990:124), and that is very clear in the EAC countries where chance events play significantly more role in the economies than in developed countries. The most important chance events affecting EAC are fluctuations in world commodity prices and world economy, policies of foreign governments and international organizations towards aid, the El-Nio in the Pacific Ocean, and war.

The EAC countries are very dependent on fluctuations in the world's commodity prices and they can create recessions or economic booms. For instance, the 11.5 percent growth in Uganda's GDP in 1995 coincided with sharp rise in world coffee prices to USD1.52 per pound which is nearly three times the average market price in 2001 one of the decade's bottoms. In 2009 the coffee price was back to the USD1.50 per lbs range. Whereas coffee constitutes more than one half of Uganda's total exports any change in coffee prices is going to have major impact on the economy in the country (UNCTAD-ICC, 2001; ICO, 2009).

The 2008 credit crunch and the resulting world recession appears to have little negative effect on the region and in some aspects may have help the EAC countries as the price of fuel and other essential imports declined while the price of agricultural commodities remained high. Albeit negative forecasts and some decline in the tourism and flower exports most industries in the EAC were unaffected or experience growth for most of 2009 (Odhiambo, 2009).

The policies of foreign governments and international organizations towards aid and loans significantly impact the economies of the EAC. For example, the International Monetary Fund (IMF), most governments, and international institutions suspended aid and lending to Kenya in 1997 and 2002. Accordingly, Kenya plunged into recession and remained there until aid and lending resumed (Redfern, 2004; UNCTAD, 2004; Zigomo, 2009).

An El-Nio is a change in the ocean currents in the Pacific Ocean and it impacts the rainfall in East Africa. El-Nio (sometimes spelled Nino or Ninyo) occurs every 3-4 years when the ocean currents of the Pacific cost of South America change the direction of their usual flow. The El Nio normally begins at Christmas time and lasts 8-9 months (Baker, 1997; Edugreen, 2005). The El Nio changes the weather pattern in East Africa and results in a year of drought reducing agricultural output. After the El-Nio disappears, a year of heavy rainfall usually follows resulting in bumper crops and economic prosperity. After an El Nio occurred in 2001 many areas of the EAC 
were severely affected. Another El Nio resulted in a drought in late 2004 causing crop failures and reduction in hydro electricity generation, similar effects were experienced in 2007, and in early 2010 rains following an El Nino drown people after a prolonged drought (China View, 2005; BBC News, 2005; NYT, 2010).

War and conflict have a negative impact on the economies in the EAC and the level of impact is related to the intensity of the conflict. Outright wars wreck the economies like happened in the civil war in Uganda between 1972 and 1986. An involvement in the internal conflict in other countries has significant consequences too like happened in 1998 when Uganda got involved in the revolution in Zaire. Though the official GDP rose by 5.6\% it was boosted by another sharp rise in world coffee prices to USD1.30 per pound. Meanwhile, many sectors of the economy suffered sharp decreases in economic activity and deflation (UNICTAD, 2001; ICO, 2009). Albeit the cost of maintaining a substantial army the low intensity conflicts carried out by the many rebel movements operating inside the EAC countries appear to have little effect on the economies of the EAC as the conflicts are usually limited in scope and are located in remote areas where little economic activity takes place.

\section{Conclusions}

The formation of the East African Community Internal Market in 2010 created an untapped rapidly growing market of 126 million people that has received little attention by international business and business researchers. The rapid growth has been driven by the liberalization of the economies and high factor investment from abroad. The retail environment in the EAC is undeveloped and unsophisticated. Thus it provides great opportunities for international retailers. Product strategy should emphasize low cost medium quality products due to limited competition, price elasticity, and emphasize their foreign origin or brand. Distribution strategies need to address longer distribution channels and frequent interruptions in supply. The most cost effective promotion medium is radio. Competitive intensity and rivalry is low and the fragmented ownership of businesses creates opportunities for consolidation of industries. The role of chance is significantly higher than most expect. The main restraints on marketing in the EAC are insufficient management, marketing, and technical knowledge, war, and corruption.

\section{Managerial implications}

The managerial implications rising from the formation of the EAC Internal Market in 2010 are many. The managers of international businesses need to give the East African Community a serious consideration and allocate resources to formulate strategies for entering the market. Business researchers need to facilitate the understanding of the EAC market by researching the various aspects of doing business there. Management should consider investing in privatized public enterprises and providing goods and services to the economic sectors benefiting from foreign factor investment such as physical infrastructure and education. International businesses should use their marketing and retailing expertise to establish competitive advantage before local businesses become entrenched in the market. Moreover international businesses should exploit their economic of scale to cash in on the price sensitivity and customer's preference for foreign brands before local businesses build these capabilities. The local businesses should consolidate their competitive advantage to ward off further entries of international firms by mergers and acquisitions. Managers need to deal with longer distribution channels and supply interruptions by establishing direct delivery, distribution centers, and reserve inventories. Most of the advertising budget should be spent on radio advertising in local languages. Contingency planning should be done to deal with the many discontinuities in the marketing environment and financial reserves should be kept on hand to exploit opportunities. Human resource development should be emphasized to deal with insufficient management, marketing, and technical knowledge.

\section{References}

Baker, G. (1997). El Nio and the Southern Oscillation Index (updated). Statistics Group, 29 September 1997. Research Note 9 1997-98. Parliament of Australia, Parliament Library. [Online] Available: http://www.aph.gov.au/library/pubs/rn/1997-98/98rn09.htm (12/28/2009).

Barigye, T. (2008). New supermarkets pose stiff challenge to local business. The New Times. [Online] Available: http://allafrica.com/stories/200812110289.html (December 15, 2009).

Batra, R. (1997). Executive insights: Marketing issues and challenges in transitional economies. Journal of International Marketing, 5(4), 95.

BBC News World Edition. (2005). Food appeal for drought-hit Kenya, October 8th. 2004. [Online] Available: http://news.bbc.co.uk/2/hi/africa/3550958.stm (1/28/2005).

BBC News World. (2009). East African nation agree to common market trade deal. [Online] Available: http://news.bbc.co.uk/1/hi/8370027.stm (December 21, 2009). 
China View. (2005). Drought reduces Uganda's hydro-power generation capacity. Jan 28th 2005. [Online] Available: http://news.xinhuanet.com/english/2005-01/28/content_2517277.htm (1/28/2005).

CIA. (2004). World Fact Book 2004. [Online] Available: http://cia.gov/cia/publications/factbook/geos/ug.html $(11 / 02 / 2004)$.

CIA. 2010. World Fact Book .(2010). [Online] Available: https://www.cia.gov/library/publications/the-world-factbook/ (January $\left.2^{\text {nd }}, 2010\right)$.

Darley, W.K. (2001). The Internet and Emerging E-Commerce: Challenges and Implications for Management in Sub-Saharan Africa. Journal of Global Information Technology Management, 4(4), 4.

EAC Int. (2010). EAC quick facts. [Online] Available: http://www.eac.int/ (January $\left.6^{\text {th }}, 2010\right)$.

EAC. (2004a). East African Community, History. [Online] Available: www.eac.int/history.htm (November 3rd, 2004).

EAC. (2004b). East African Community, About EAC. [Online] Available: www.eac.int/about_eac.htm (November 3rd, 2004).

Edugreen. (2005). El Nino. Edugreen. [Online] Available: http://edugreen.teri.res.in/explore/climate/elnino.htm (January 1, 2004).

FAO. (2005). Rise of supermarkets across Africa threatens small farmers: Opportunities and challenges in a changing market. Food and Agricultural Organization, Rome, October 8th. (2003). [Online] Available: http://www.fao.org/english/newsroom/news/2003/23060-en.html (January 17, 2005).

http://econ.worldbank.org/WBSITE/EXTERNAL/EXTDEC/0,menuPK:476823 pagePK:64165236 piPK:64165 141 theSitePK:469372,00.html (December 17, 2009).

International Coffee Organization (ICO). (2009). Historical Price Data. [Online] Available: http://dev.ico.org/prices/p2.htm (January 5, 2010).

Juuko, S. (2004). The International monetary Fund(IMF) says Uganda's economy will grow by 5.5\% during 2005. All Africa. [Online] Available: http://allafrica.com/stories/200412240095.html (December 30, 2004).

Kasumuni, L. (2005, January 24). Goods enjoying EA Custom union tariff cut, IPPMedia-Guardian. [Online] Available: http:/www.ippmedia.com/ipp/guardian/2005/01/27/30981.html (January 27, 2005).

Kigotho, W., and Bollag. B. (2002, July, 12). A tale of rebirth: Makerere U. survived a dictator's reign and is thriving again. The Chronicle of Higher Education, 48(44), p. A41.

Kristiansen, S., \& Ryan, A. (2002). Enacting their business environments: Asian entrepreneurs in East Africa. African and Asian Studies, 1(3), 165-186.

Mueller, Rene D., J. Winthe and P. Baron. (1993). Case Note: The Evolution of Distribution Systems. International Marketing Review, 10(4), 36-52.

Muna Wahome. (2004, December 7). New Uchumi Investor to Take 35 P.c. The Nation (Nairobi). [Online] Available: htt/:allafrica.com/stories/200412070500.thml (January 17, 2005).

Nairobi Stock Exchange (NSE). (2005). History. [Online] Available: http://www.nse.co.ke/ (January 30, 2005).

New York Times (NYT). (2010). Official: 21 drown in floods in Kenya. [Online, January $5^{\text {th }}$, 2010] Available: http://www.nytimes.com/aponline/2010/01/05/world/AP-AF-Kenya-Floods.html (January 5th, 2010).

Nord, R., De Masi, P., Green, J., Gupta, S., Pattillo, C., Shields, J., Tsangarides, C., Weisfeld, H., and Yang, Y. (2004). Sub-Saharan Africa Regional Economic outlook: October, 2004. International Monetary Fund, Washington, D.C.

Nyakundi, L. (2008). Telecom sponsors Ugandan football club. [Online] Available: http://africa.bizcommunity.com/Article/220/48/24148.html (December 20th, 2009).

Ochieng, W. (2009). Kenya: Market info: kiosk and radio. [Online] Available: http://www.regoverningmarkets.org/en/resources/support_agencies/kenya_market_information_rural_kiosks_and radio (January 1, 2010).

Odeu, S. (2004, June, 2004). Customs Union to Start On Jan 1, International Communications, (Nairobi). [Online] Available: http://allafrica.com.stories/200412240096html (December 26, 2004).

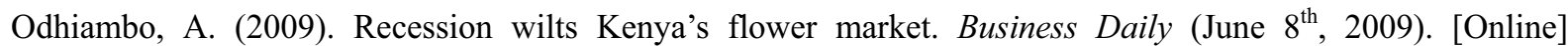
Available: http://www.businessdailyafrica.com/-/539552/607890/-/55315r/-/index.html (December 20 ${ }^{\text {th }}, 2009$ ). 
Omondi, P. (2001, March/April). Quality remains the prime concern for tea producers. Agricultural Review, [Online] Available: http://www.readafrica.com/0202020227amag.html\#anchor894791 (January 30, 2005).

People's Daily Online. (2005, January 14). China's FDI witnesses 13\% growth in 2004. [Online] Available: http://search.people.com.cn/was40/people/GB/english_index.jsp?type=1\&channel=(January 26, 2005).

Porter, M. E. (1990). The Competitive Advantage of Nations. New York, NY, PALGRAVE.

PricewaterhouseCoopers(PWC). (2004). Uganda Issues - Trends in Manufacturing, Consumer and Industrial Products Sector. [Online] Available: http://www.pwcglobal.com/extweb/home.nsf/docid/AACFF70339902F54080256CD0030419E (November 23, 2004).

Ramamurty, T. (2009). Nakumatt enters Uganda. [Online] Available: http://www.regoverningmarkets.org/en/news/east_africa/nakumatt_enters_uganda.html (January 3, 2010).

Redfern, P. (2004, January). International Communications. [Online] Available: http://proquest.umi.com/pqdweb?index (December 20, 2004).

Reuters. (Jan 7, 2010). Kenya Uchumi supermarkets' annual pretax up 60ct. [Online] Available: http://af.reuters.com/article/idAFJOE60605T20100107 (January 7th, 2010).

Sameii, Saeed. (1993). Retailing and channel considerations in developing countries: A review and research propositions. Journal of Business Research, 27, 103-130.

Sylvester, E. (2005, January 17). Britain calls on African debts written off. Associated Press. [Online] Available: http://news.yahoo.com/news?tmpl=story\&u=/ap/20050117/ap_on_re_af/africa_britain (January 18, 2005).

Transparency International. (2006). The 2006 Transparency International Corruption +Perceptions Index. [Online] Available: http://www.infoplease.com/ipa/A0781359.html (January 4th, 2010).

Trent, R. (2002). Implications for foreign direct investment in Sub-Saharan Africa under the African Growth Opportunity Act. Northwestern Journal of International Law and Business, 23(1), 213.

UNCTAC. (2000). UNCTAD World Investment Report 2000: Mergers and Acquisitions and Development. New York and Geneva, United Nations Publication, No. E.00.II.D.24

UNCTAD. (2004). Least Developed Countries Report 2004: Linking International Trade and Poverty Reduction. New York and Geneva, United Nations Publication ISBN:92-1-112581-2. [Online] Available: http://www.unctad.org/Templates/Page.asp?intItemID=1676\&lang=1 (January 20, 2005).

UNCTAD-ICC. (2001). An Investment Guide to Uganda. New York and Geneva, United Nations Publication UNCTAD/ITE/IIT/Misc.30, Internet Edition. [Online] Available: from http://www.unctad.org (December 1, 2004).

UNDP. (2004). Human Development Report. New York and Geneva, United Nations Publication. [Online] Available: http://hdr.undp.org/statistics/ (February 3, 2005).

UNICTAD. (2005, November, 1). World FDI Flows Grew an Estimated 6\% in 2004, Ending Downturn, Press Release, UNCTAD/PRESS/2005/002. [Online] Available: http://globaledge.msu.edu/ibrd/offsite.asp?URL=http $\% 3 \mathrm{~A} \% 2 \mathrm{~F} \% 2 \mathrm{Fwww} \% 2$ Eipanet $\% 2 \mathrm{Enet} \% 2 \mathrm{~F} \&$ ResourceCate goryID $=4 \&$ CategoryTitleText $=$ Research $\% 3 \mathrm{~A}+$ Multi $\% 2 \mathrm{DCountry} \&$ ResourceLinkText $=$ World + Bank $\% 3 \mathrm{~A}+\mathrm{IPAn}$ et (February 3, 2005).

United States Commercial Service(USCS). (2005). Country Commercial Guide: Tanzania. [Online] Available: http://www.export.gov/comm_svc/(January 23, 2005).

Virtual Nairobi: Shopping. (2005). [Online] Available: http://www.kenyaweb.com/vnairobi/shopping.html (January 17, 2005).

Weatherspoon, D.D., \& Reardon T. (2003). The rise of supermarkets in Africa: Implications for agrifood systems and the rural poor. Development Policy Review, 21(3), 333-355.

Wijk, J. (2006). Food retailing: the rise of supermarkets. Roundtable Africa. [Online] Available: http://www.roundtableafrica.net/round-tables/in-europe/partnering-with-africa/workshops/supermarkets/ (December 11, 2009).

Woolworths. (2010). Store [Online] locator. Available: http://www.woolworths.co.za/Caissa.asp?Page=ITB4_RHConText\&Post=CO-Stores_Franchise $\quad\left(\right.$ January $5^{\text {th }}$, 2010). 
World Bank. (2004). World Development Indicators 2004. Washington D.C. World Bank Publication. [Online] Available: http://www.worldbank.org/data/countrydata/countrydata.html (1/26/3005).

World Bank. (2009). World Development Indicators 2009. Washington D.C. World Bank Publication. [Online] Available:

Zigomo, M. (2009). Uganda coffee exports withstand recession. Reuters [Online] Available: http://af.reuters.com/article/investingNews/idAFJOE55E0H420090615 (December 19th, 2009). 